\title{
The effect of cover system depth on native plant water relations in semi-arid Western Australia
}

\author{
SC Lamoureux The University of Western Australia and O'Kane Consultants, Australia \\ EJ Veneklaas The University of Western Australia, Australia \\ P Poot The University of Western Australia, Australia \\ M O'Kane O'Kane Consultants, Canada
}

\begin{abstract}
Cover systems utilising the store and release concept, i.e. evapotranspiration (ET) covers, are reliant on plant transpiration and evaporation to preclude percolation (deep drainage) into waste rock, thus minimising the risk of releasing potentially contaminated seepage. However, attaining persistent plant communities on ET covers is especially challenging in water limited environments. Soil texture permitting, greater water storage may be achieved through increased cover thickness. This study quantified cover material water dynamics, growth, and water use of native Australian plants over one year to determine if differences in plant performance were associated with species, plant available water, and cover thickness on a 1.5 year old irrigated ET cover in a semi-arid region. Plant height growth varied between species but not with cover thickness. Average transpiration per unit leaf area and stomatal conductance $\left(g_{s}\right)$ were 1.2 and 2.3 times higher in winter than in summer, respectively, and tended to be higher on thicker covers for both seasons. Overall, transpiration rates were positively correlated with soil volumetric water content (VWC, average from 0.0-0.3 m), but differed between species. Transpiration tended to increase with VWC, $g_{s}$, and cover thickness $(0.7>0.5>0.3 \mathrm{~m})$, indicating plant (stomatal) control of transpiration in response to drought stress associated with cover thickness. The analysis suggests that plants on thicker covers transpired at greater rates due to access to stored water at greater depths, resulting in higher overall transpiration. This work demonstrates the importance of quantifying water use differences between species, seasons, and cover thicknesses during cover system modelling and design phases. It also highlights the potential for greater plant available water by increasing cover thickness, aiding the establishment of self-sustaining plant communities on ET covers.
\end{abstract}

\section{Introduction}

The relationship between plant ecophysiology and engineered cover design is essential to effective cover system performance. Engineered cover systems are commonly used atop hazardous mine waste to limit water infiltration to environmental receptors, especially in water limited systems where potential evapotranspiration (ET) far exceeds annual precipitation (Gwenzi et al. 2014). Cover systems utilising the store and release concept (ET covers) are grounded on water balance principles, whereby infiltrating rainfall is stored for subsequent atmospheric release by ET (Albright et al. 2004; O'Kane \& Ayres 2012; Gee et al. 2006). Vegetation is key to controlling the water balance of ET covers by precluding percolation (deep drainage) below the root zone through root water uptake (Scanlon et al. 2005b; Seyfried et al. 2005; Scanlon et al. 2005a).

Although field and modelling studies have documented the applied hydrological benefits of vegetation on engineered covers (Scanlon et al. 2005b; Fayer \& Gee 2006; Eamus et al. 2013), few have determined the water use patterns and ecophysiology at the species or communities level. Because the ecophysiology of species and community types vary, an understanding of the patterns is important for revegetation of engineered covers. For instance, at the community level, Yunusa et al. (2010) concluded a grass cover restricted ET to $75 \%$ of rainfall due to shallow rooting and seasonal growth compared to a woodland at $85 \%$ of rainfall. At the species level, Szota et al. (2011) observed higher summer stomatal conductance ( $g_{s}$ ) for 
Eucalyptus marginata versus Corymbia calophylla co-occurring on a restored bauxite mine site. Although these two species persisted on the same rehabilitated site, their water use rates and physiological mechanism for drought tolerance varied (Szota et al. 2011). Water use differences at the community and species level are apparent but little empirical data exists for vegetation on engineered covers.

Species and community level water uptake, however, is dependent on soil physical characteristics and plant traits. Soil texture greatly influences soil water storage due to variation in pore size and its effect on hydraulic conductivity (Jury \& Horton 2004; Sperry \& Hacke 2002; Hacke et al. 2000). Soil texture thus results in different challenges for plant water extraction (Bristow et al. 1984). Under drought stress, plants native to different soil textures have different traits and contrasting water use strategies to facilitate plant water extraction. In semi-arid to arid systems, remaining physiologically active under drought stress hinges on the ability of plants to tolerate high xylem tensions enabling water uptake from very dry soils to the leaves, or alternatively, closing stomates to limit water use while enduring high shoot temperatures and long periods without carbon (Bhaskar \& Ackerly 2006; Seyfried et al. 2005). Maintaining adequate contact at the root-soil interface to maintain hydraulic conductance is central to water extraction, especially in dry systems where water is limiting and soil texture is variable (Sperry et al. 1998).

Though soil texture influences hydraulic conductance at the root-soil interface, available soil volume for root exploration, and soil water storage, it is also essential for plants to remain physiologically active in water limited systems. Engineered covers are in part designed to enhance soil water retention (Yunusa et al. 2010), providing that material hydraulic properties are conducive to storage (Gwenzi et al. 2014). Therefore, with suitable cover material, it is possible to enhance plant available water by increasing cover thickness. Enright and Lamont (1992) found that Banksia survival on a rehabilitated mine site was limited by a combination of three factors: impedance to root penetration into denser subsoils restricting roots to surface layers, inadequate soil water in the topsoil layer, and an inability of roots to keep pace with the drying front. They suggested an increase in total cover depth with an unconsolidated sandy layer below the topsoil. This would allow seedlings to establish roots at depths where water was less limiting during summer when evaporation far exceeded precipitation (Enright \& Lamont 1992). Similarly, Szota et al. (2007) observed approximately 2.4 times greater stand density for Eucalyptus marginata on a thicker versus thinner ripped restored site. Higher tree density at the thicker site was attributed to greater soil volume exploitation by roots, and better material properties, resulting in deeper tap and sinker root establishment into soil with higher water storage capacity (Szota et al. 2007). In agreement with Enright and Lamont (1992), it was predicted that trees on the thinner site would undergo water stress much earlier during summer due to restriction of roots to the top 0.5-0.6 $\mathrm{m}$ of the soil (Szota et al. 2007). Gwenzi et al. (2014) further corroborated the importance of soil texture in relation to greater cover depth with the purpose of increasing soil water storage. They demonstrated that enhanced plant available water resulting from increased cover thickness was not achievable in a bauxite residue sand $(>150 \mu \mathrm{m}$ ) area due to high hydraulic conductivity (Gwenzi et al. 2014; Gwenzi et al. 2011). Therefore, it is important to recognise that optimal engineered cover thickness is site and material specific (Gee et al. 2006; Albright et al. 2004), and should be based on the interactions of several factors including texture, climate, and plant community requirements (Arora 2002; Arnold et al. 2015).

To improve the understanding of ET cover thickness effect on soil water storage, species growth, and seasonal water use, six native Australian plant species were established and monitored over one year on an irrigated ET cover at three cover thicknesses in a semi-arid region. We hypothesised (1) that thicker covers would store more water compared to thinner covers leading to greater plant growth, and water use, (2) winter water use would be higher compared to summer, particularly for plants on thinner covers due to faster depletion of stored water during summer. 


\section{$2 \quad$ Materials and methods}

\subsection{Study site characteristics}

The study was conducted in the Yalgoo region of Western Australia at Mount Gibson Mining Limited, Extension Hill Hematite Operation (29 $\left.34^{\prime} 14.7^{\prime \prime S}, 117^{\circ} 10^{\prime} 15.6^{\prime \prime} \mathrm{E}\right)$, located approximately $293 \mathrm{~km}$ northeast of Perth. The Yalgoo region is characterised as semi-arid with two distinct seasons, hot summers from October to March, and warm to cool winters from April to September during which the majority of rainfall occurs. Mean annual rainfall is low, approximately $338 \mathrm{~mm}$ with high annual potential evaporation exceeding 2,200 mm (Bureau of Meteorology, http://www.bom.gov.au). The region is dominated by mulga (Acacia aneura), bowgada (A. ramulosa var. linophylla), and Eucalyptus species open woodlands and scrubs on sandy and alluvial plains, in addition to rocky outcrops and banded ironstone communities (McKenzie et al. 2003).

The ET cover system trial plots were constructed atop a waste rock dump slope $\left(18^{\circ}\right)$ with a northeast aspect. Waste rock in the dump is dominated by banded iron formation (BIF), hematite, and goethite comprising $94.8 \%$ of the total waste volume (Landloch Pty Ltd 2012). The ET cover system material was comprised of a 2:1 BIF/topsoil mix. Topsoil was sourced from pre-mining stockpiles of no more than $2 \mathrm{~m}$ high. The cover material was mixed by spreading from the top of the dump to its bottom using a bulldozer with GPS capabilities. The engineered cover was spread into three thicknesses: $0.3,0.5$, and $0.7 \mathrm{~m}$ at a precision of $\pm 0.1 \mathrm{~m}$, with each thickness having six replicates totalling 18 monitoring plots.

Six local provenance native species from two contrasting community types were chosen for this study. Species in this area were classified as typically from sandy or rocky community types based on evidence gathered from pre-mining vegetation surveys (ATA Environmental 2006; Bennet Environmental Consulting 2000; Griffin and Associates 2005), literature (Payne 1997; McKenzie et al. 2003; Meissner \& Caruso 2008), expert consultations, onsite knowledge, and Flora Base (http://florabase.dpaw.wa.gov.au/) (Table 1).

Table 1 Local species planted on cover system trial plots in relation to the typical soil type they occur on in the Mount Gibson mining area

\begin{tabular}{cc}
\hline Rocky soil & Sandy soil \\
\hline Eucalyptus leptopoda & Eucalyptus loxophleba \\
Acacia alata & Acacia acuminata \\
Melaleuca nematophylla & Melaleuca cordata \\
\hline
\end{tabular}

Six month old seedlings were planted in early July 2014 at the centre of every cover system plot in a 6 by 6 plant configuration $0.5 \mathrm{~m}$ apart. The outermost plants were $1 \mathrm{~m}$ from the edge of every plot. Within each vegetated plot, six seedlings per species were planted at random. A total of 648 seedling were planted, with 36 seedlings per species for every cover thickness. A pump-fed drip irrigation system $\left(1.6 \mathrm{~L} \mathrm{hr} r^{-1}\right)$ was constructed and assembled onsite shortly after planting. Drip lines were extended between every seedling row on all plots to ensure equal watering. Seedlings were irrigated twice weekly for 15 minutes with potable water during the first monitoring year to ensure establishment and persistence. The entire monitoring area was enclosed with rabbit fencing to avoid herbivory by small mammals.

\subsection{Soil analysis}

Representative bulk soil samples were collected from across all plots and slope positions for geochemical and geotechnical analysis. No major geochemical restrictions to plant growth were apparent and seedlings did not show signs of nutrient deficiency or toxicity. Samples were sent to Soil Water Group for physical analysis, including soil texture (classes: $0.02>$ sand $<2.0,0.002>$ silt $<0.02$, clay $<0.002 \mathrm{~mm}$; Wet Chemistry Method), particle size analysis $>0.075 \mathrm{~mm}$ (sieve analysis; Australian Standard 1289.3.6.1 2009), and laboratory saturated hydraulic conductivity $\left(K_{\text {slab }}\right)$ (constant head method; Australian Standard 1289.6.7.1 2001). Field saturated hydraulic conductivity $\left(K_{\text {sfield }}\right)$ was measured in triplicate at every soil sample location using a 
Philip-Dunne permeameter (Muñoz-Carpena et al. 2002). The design, field protocol, and calculations of $K_{\text {sfield }}$ followed detailed procedures outlined by Muñoz-Carpena et al. (2001) and Muñoz-Carpena et al. (2002).

\subsection{Field methods}

Continuous field soil volumetric water content (VWC; $\mathrm{m}^{3} \mathrm{~m}^{-3}$ ) was measured using CS616 moisture content reflectometers split between one CR 800 and two CR 10X dataloggers routed via AM 16/32B multiplexers (Campbell Scientific Inc.). Data acquisition was split between three monitoring stations (three dataloggers) as a precaution in case of datalogger failure. Dataloggers were programmed to store VWC readings every four hours. Volumetric water content sensors were installed on every cover plot prior to planting seedlings. Sensors were installed at $0.2 \mathrm{~m}$ depth intervals to the maximum depth of every cover. That is, $0.3 \mathrm{~m}$ thick covers had sensors at 0.1 and $0.3 \mathrm{~m} ; 0.5 \mathrm{~m}$ thick covers, had sensors at $0.1,0.3 \mathrm{~m}$, and $0.5 \mathrm{~m}$; and $0.7 \mathrm{~m}$ thick covers had sensors at $0.1,0.3,0.5$, and $0.7 \mathrm{~m}$.

Meteorological variables on the plots were measured by an automated weather station (central monitoring station; CR 800). The station measured air temperature and relative humidity (CS215 Campbell Scientific Inc.), Wind speed (Ws) and direction (Wd) (Wind Sentry 03002, RM Young Pty. Ltd.), solar radiation (Rs) (SP-110 pyranometer, Apogee Instruments Inc.), and rainfall using a tipping bucket rain gauge (CS 703, Campbell Scientific Inc.). Meteorological variables were programmed to be collected every 15 minutes with compiled hourly and daily data.

Plant physiological monitoring was conducted quarterly on one seedling per species for every plot. During

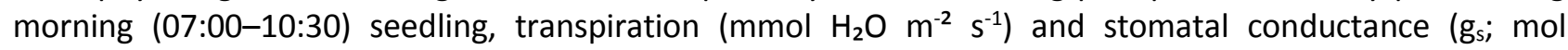
$\mathrm{H}_{2} \mathrm{O} \mathrm{m}^{-2} \mathrm{~s}^{-1}$ ) were measured using an LI-6400XT Portable Photosynthesis System (LI-COR). Seedlings were sampled by clamping the leaf chamber onto a leaf and taking five readings per plant. Leaf area in the chamber was calculated by measuring the length and width of the leaves. The light source in the chamber was an artificial red and blue LED delivering a photosynthetic photon flux density of $1,500 \mu \mathrm{mol} \mathrm{m}^{-2} \mathrm{~s}^{-1}$. Temperature in the leaf chamber was kept as close to ambient as possible. Reference gas concentration of $\mathrm{CO}_{2}$ was kept constant at $405 \mathrm{\mu mol} \mathrm{mol}^{-1}$, and the flow rate was adjusted to ensure a leaf chamber $\mathrm{CO}_{2}$ depletion of at least $5 \mu \mathrm{mol} \mathrm{mol}{ }^{-1}$. The leaf chamber thermocouple was adjusted to be below the leaf, and the energy balance equation was used to calculate leaf temperature (LI-COR Inc. 2011). Plant physiological variables were computed by the LI-6400XT through equations derived by von Caemmerer and Farquhar (1981). Plant height $\left(H_{\max }\right)$ was taken using a meter stick from the base of the plant to the highest point of the foliage by extending all parts of the plant upwards (Pérez-Harguindeguy et al. 2013). Quarterly plant height growth was computed using the difference between the second time step $\left(H_{\max 2}\right)$ and first time step $\left(H_{\max 1}\right)$.

\subsection{Data analysis}

Data was analysed with RStudio statistical software (R Core Team 2013). Differences in $K_{\text {sfield }}$ and $K_{\text {sLab }}$ were tested using generalised least square (gls) models where slope position and cover thickness were fixed factors using the package nlme (Pinheiro et al. 2015). Differences in plant height growth for species and cover thickness were tested using mixed effects models where species and cover thickness were fixed factors and slope position was a random factor using the package Ime4 (Bates et al. 2014). Linear mixed effects modelling was conducted to determine the relationship between transpiration, and $g_{s}, V W C$, and cover thickness. Where the response variable was transpiration, fixed factors were $g_{s}$, VWC, and cover thickness (with interaction terms), and random factors were air temperature and $\mathrm{RH}$ of the sample chamber using the package Ime4 (Bates et al. 2014). All three analyses incorporated weighted variance structures (VarFixed, VarIndent, VarPower, VarExp, and VarConstPower) to ensure homogeneity of variance as outlined in Zuur et al. (2009). Models were evaluated and selected using Akaike's information criterion, (AIC; a measure of relative model quality for a given set of data), and plots of standardised residuals for visual inspection of homoscedasticity and normality. Models with the lowest AIC value and with homogeneity of variance were chosen for further analysis. Differences in plant height growth and the relationship between transpiration and the fixed factors were tested for significance using analysis of variance (ANOVA) at $\alpha=0.05$ using the 
most appropriate model for each analysis. Tukey's multiple pairwise comparison test was used to analyse differences in plant height growth of species where ANOVA model outputs were significant.

\section{$3 \quad$ Results}

\subsection{Soil physical characteristics}

The cover material, a 2:1 BIF/topsoil mix, was characterised as a coarse sandy loam with a large gravel fraction (particles $>2.36 \mathrm{~mm}$ ). Cover material mean $K_{\text {sfield }}$ and $K_{\text {slab }}$ values were 0.22 and $0.18 \mathrm{~m}$ day ${ }^{-1}$, respectively. Observed mean $K_{s}$ values were within the range of those reported for deep alluvial soils $\left(0.05-14.5 \mathrm{~m}^{-1 a y^{-1}}\right)$ (Botros et al. 2009), and other engineered covers $\left(8.6 \times 10^{-7}-0.86 \mathrm{~m}^{2}\right.$ day $\left.^{-1}\right)$ (Bohnhoff et al. 2009; Ogorzalek et al. 2008). Cover material $K_{s}$ (field and lab) were homogeneous across all plots with no statistically significant $(P>0.05)$ differences between cover depths and slope positions.

\subsection{Meteorological and soil water conditions}

Rainfall and vapour pressure deficit (VPD) showed distinct seasonal patterns, (Figure 1), typical of this semi-arid location. Total annual rainfall during the period of June 2014 to May 2015 was 308 mm occurring mainly in winter, although some small isolated showers occurred in summer (Figure 1). The observed annual rainfall was $30 \mathrm{~mm}$ less than the long-term average $(338 \mathrm{~mm}$ ) for Mount Gibson (Bureau of Meteorology, http://www.bom.gov.au). Changes in VWC corresponded well to rainfall events, especially at the shallower depths (Figure 1).
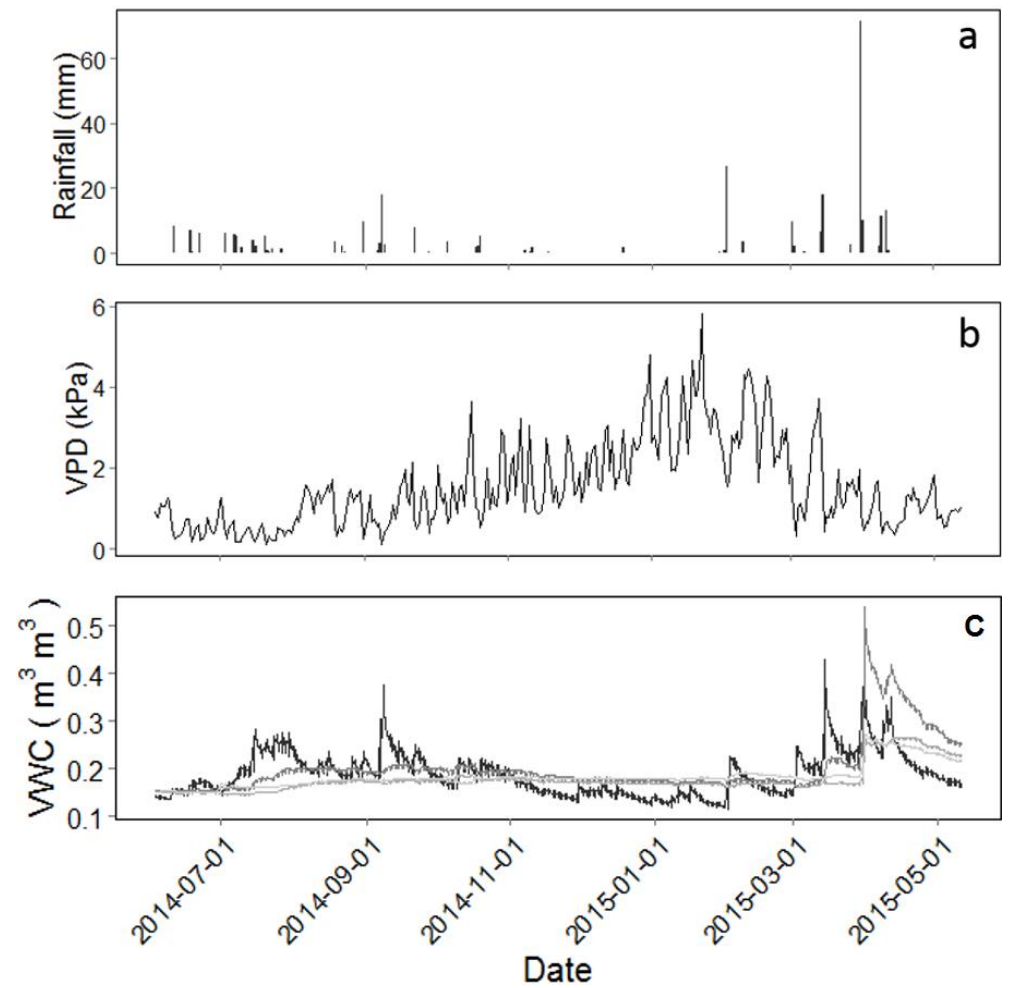

Figure 1 Seasonal patterns of (a) daily rainfall, (b) vapour pressure deficit (VPD), and (c) corresponding volumetric water content (VWC) from a $0.7 \mathrm{~m}$ thick cover at four sensor depths (from dark to light grey with increasing sensor depth; $0.1 \mathrm{~m}, 0.3 \mathrm{~m}, 0.5 \mathrm{~m}$, and $0.7 \mathrm{~m}$ ) under irrigation

Differences in VWCs did not differ significantly with cover thickness due to the presence of irrigation on all cover thickness treatments, with the exception of a higher VWC in the $0.5 \mathrm{~m}$ thick cover at a sensor depth of $0.1 \mathrm{~m}$ during summer $(P<0.01$; Figure 2$)$. Additionally, $\mathrm{VWC}$ at a sensor depth of $0.3 \mathrm{~m}$ for the $0.5 \mathrm{~m}$ and $0.7 \mathrm{~m}$ cover thicknesses were significantly $(P<0.05)$ higher compared to the $0.3 \mathrm{~m}$ cover thickness in summer and winter (Figure 2). 


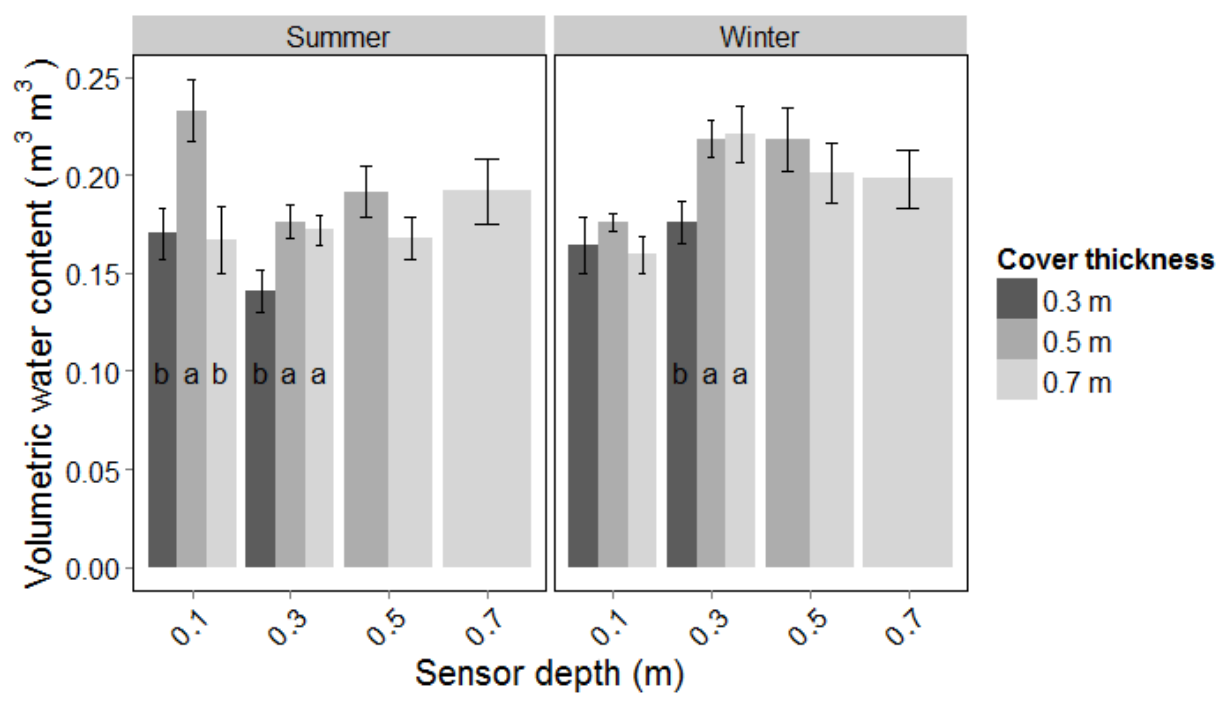

Figure 2 Mean ( \pm SE) VWC recorded during plant physiological monitoring at four sensors depths for all cover thicknesses; letters denote significant $(P<0.05)$ differences between cover thicknesses within each sensor depth

\subsection{Plant growth and water use}

After the first week of planting, seedling survival remained above $90 \%$ for all species with the exception of Acacia alata. All A. alata seedlings died during the first summer across every plot after a maximum of 92 days. Plant height growth varied significantly $(P<0.001)$ between species but not with cover thickness. Differences in plant height growth were only significantly different between species of different genera (Figure 3; $\mathrm{P}<0.001$; Tukey's multiple pairwise comparison test). Seedlings of the single surviving Acacia species had the largest quarterly growth rate, followed by the Eucalyptus species, then the Melaleuca species (Figure 3).

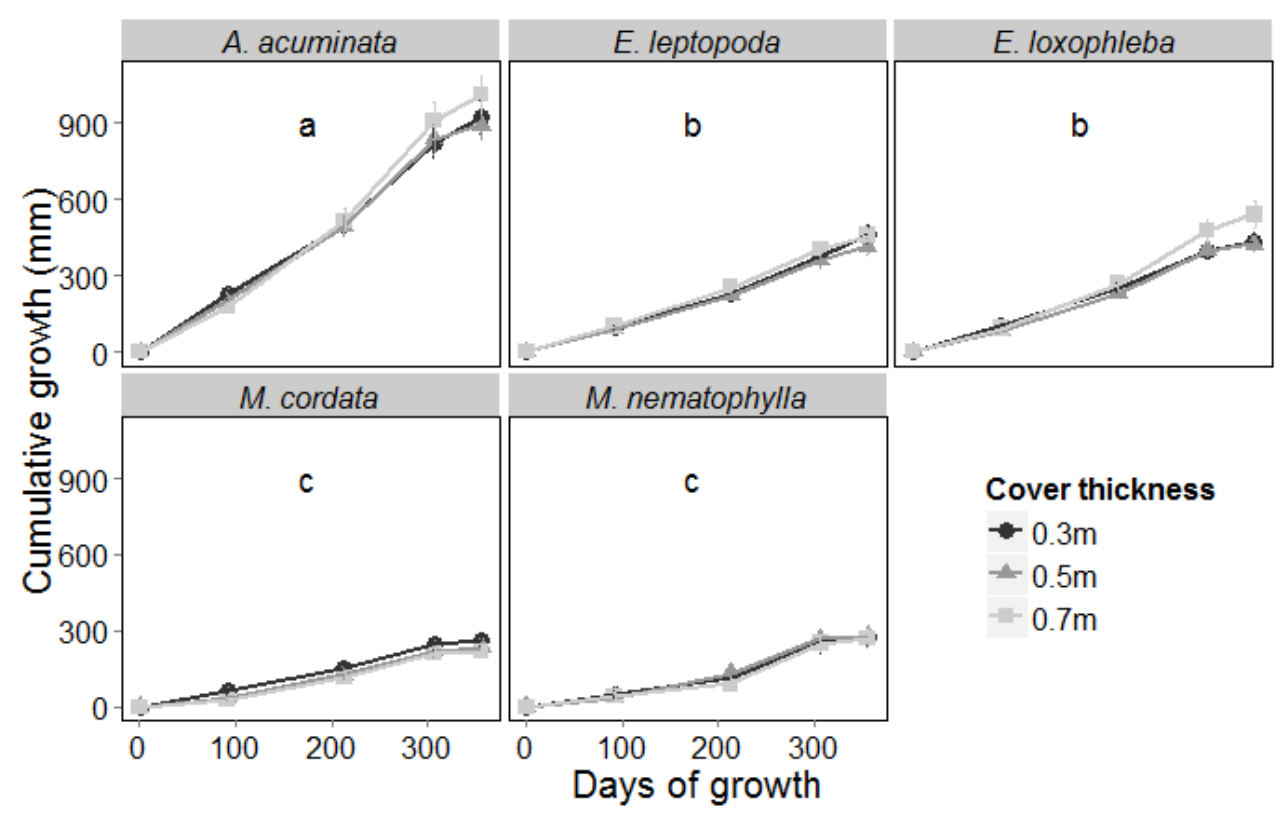

Figure 3 Cumulative growth ( \pm SE) of seedlings of five local native species: Acacia acuminata, Eucalyptus leptopoda, Eucalyptus loxophleba, Melaleuca cordata, and Melaleuca nematophylla over one year on at ET cover system in semi-arid Western Australia. Letters denote significant differences between species 
Overall, transpiration rates and $g_{s}$ were positively correlated with volumetric water content (VWC; average from 0.0-0.3 m), and differed significantly $(P<0.001)$ between species (data not shown). Mean transpiration rates across all species and cover thicknesses were affected by significant seasonal differences $(P<0.05$; Figure 4). Similarly, seasonal contrasts in $g_{s}$ were significant $(P<0.001)$, but larger compared to transpiration (Figure 4) due to high summer VPD that caused transpiration to approach winter values. Average transpiration per unit leaf area and $\mathrm{g}_{\mathrm{s}}$ were 1.2 and 2.3 times higher in winter than in summer, respectively. Although not statistically significant, water use tended to increase with cover thickness.
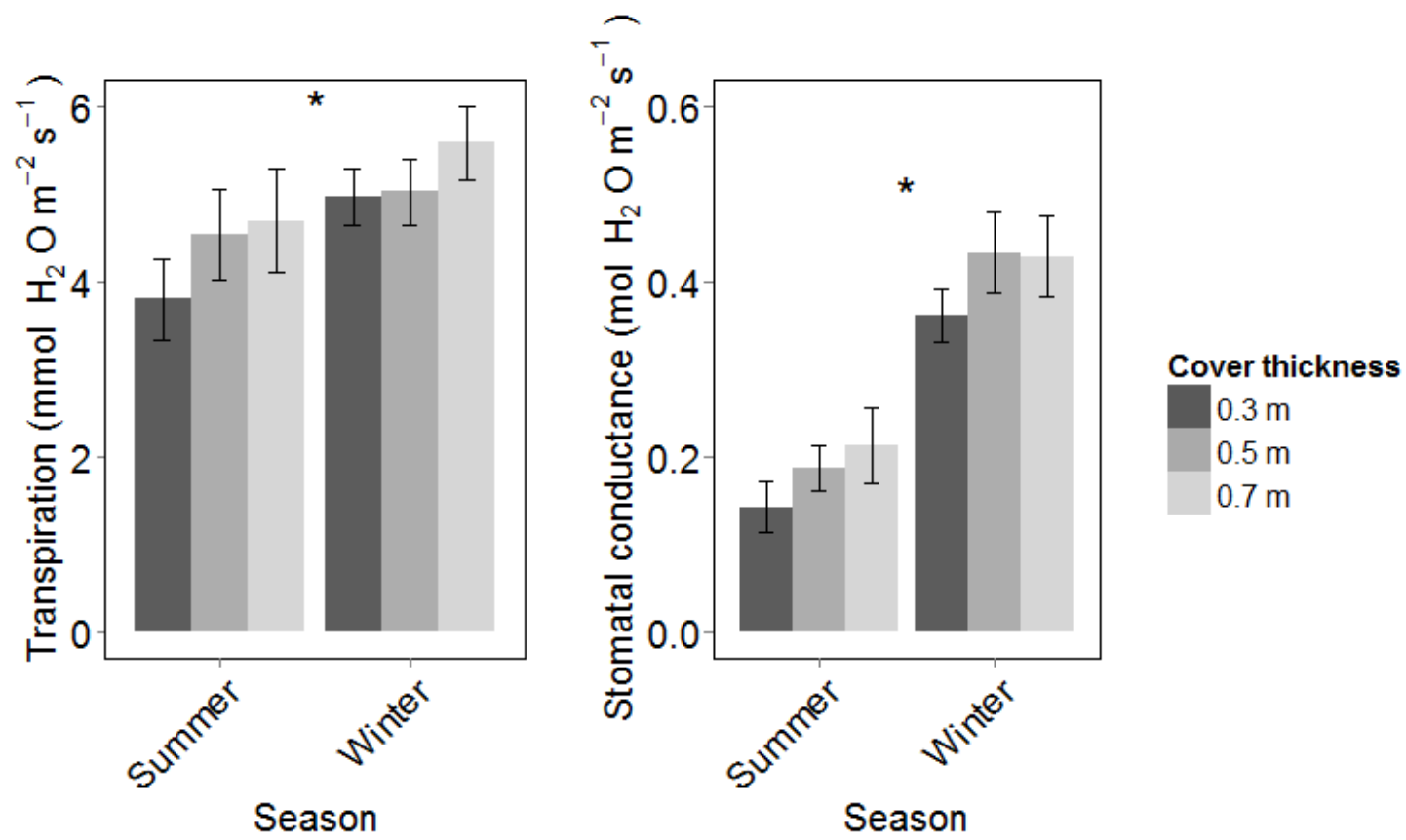

Figure 4 Mean ( \pm SE) transpiration and stomatal conductance of five native plant species: Acacia acuminata, Eucalyptus leptopoda, Eucalyptus loxophleba, Melaleuca cordata, and Melaleuca nematophylla, in summer and winter, at three cover thicknesses. Asterisks denote significant differences between summer and winter water use

The overall relationship between transpiration, $g_{s}, V W C$, and cover thickness from linear mixed effects analysis, shown by linear regression planes, indicated that transpiration increased with $\mathrm{VWC}, \mathrm{g}_{\mathrm{s}}$, and cover thickness (Figure 5). Transpiration appears to be under stomatal control in response to drought stress and is associated with cover thickness (Figure 5). Although differences between cover thicknesses under irrigated conditions were not significant, plant transpiration rates on the $0.7 \mathrm{~m}$ thick cover were approximately 9 and $16 \%$ greater than the 0.5 and 0.3 m thick covers, respectively. Similarly, $\mathrm{g}_{\mathrm{s}}$ on the $0.7 \mathrm{~m}$ cover was 2 and $23 \%$ greater compared to the 0.5 and 0.3 m covers, respectively. Interestingly, VWC on the $0.5 \mathrm{~m}$ cover was $9 \%$ greater than the $0.7 \mathrm{~m}$ cover, although both the 0.5 and $0.7 \mathrm{~m}$ covers had greater VWCs than the $0.3 \mathrm{~m}$ cover at 22 and $12 \%$, respectively. Linear mixed effects analysis for transpiration also determined that the interaction term $\left(\mathrm{gs}_{\mathrm{s}}{ }^{*} \mathrm{VWC} *\right.$ cover thickness) was significant $(\mathrm{P}<0.001)$. The interaction occurred between transpiration as it responded to VWC at a cover thickness of $0.5 \mathrm{~m}$, where the slope of the plane at $0.5 \mathrm{~m}$ was significantly steeper compared to the other cover thickness (Figure 5). Transpiration rates as a function of VWC responded more rapidly on the $0.5 \mathrm{~m}$ thick cover compared to the other two covers. 


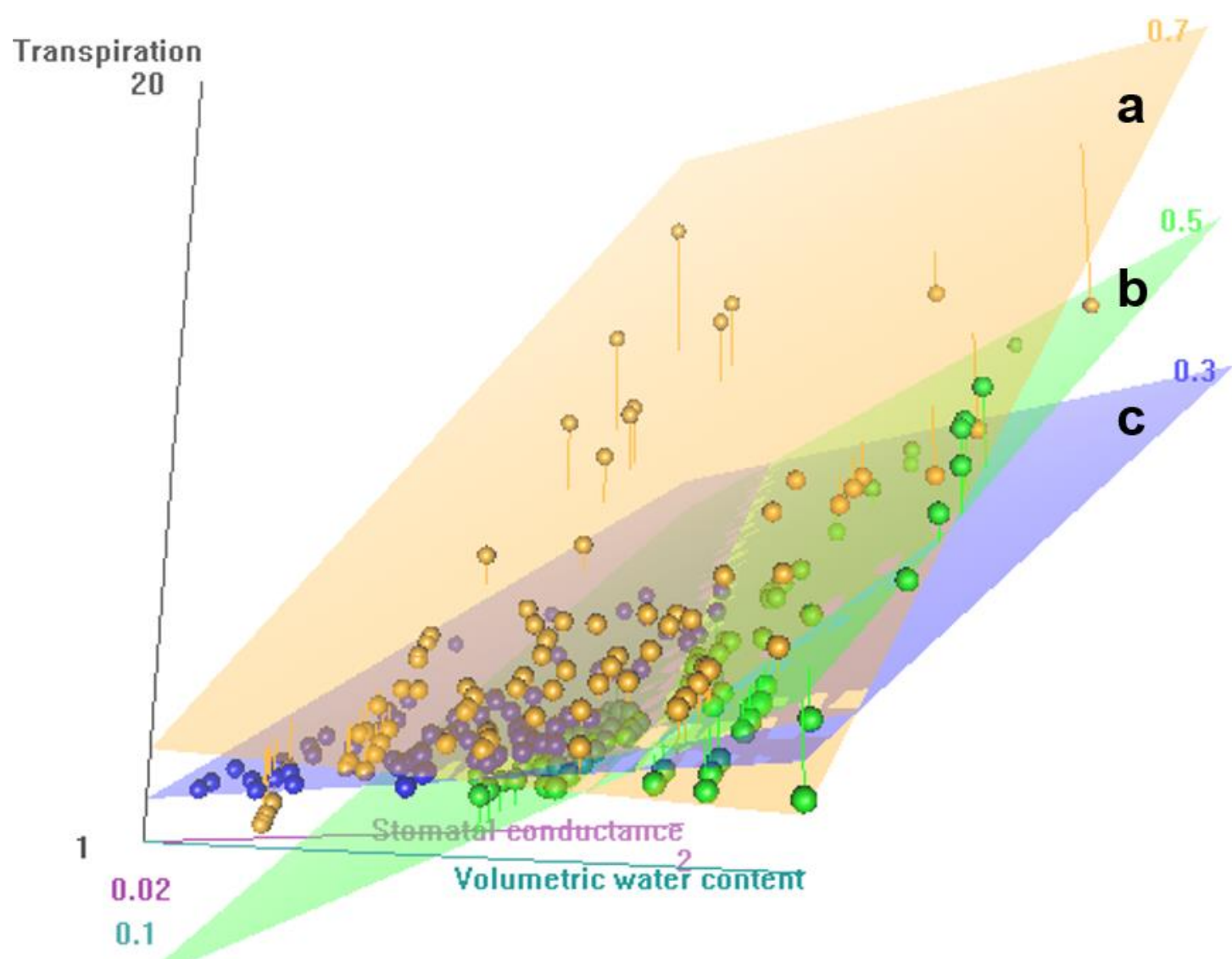

0.2

Figure 5 Three-dimensional relationship between transpiration $\left(\mathrm{mmol} \mathrm{H}_{2} \mathrm{O} \mathrm{m}^{-2} \mathrm{~s}^{-1}\right)$, stomatal conductance $\left(\mathrm{g}_{\mathrm{s}} ; \mathrm{mol} \mathrm{H} \mathrm{H}_{2} \mathrm{O} \mathrm{m}^{-2} \mathrm{~s}^{-1}\right)$, volumetric water content $\left(\mathrm{VWC} ; \mathrm{m}^{3} \mathrm{~m}^{-3}\right)$, and cover thickness $(\mathrm{m})$, where points represent the effect on the scale of the linear predictor for all combinations of predictor values from linear mixed effects analysis; linear regression planes represent cover thickness $(a=0.7 \mathrm{~m}, \mathrm{~b}=0.5 \mathrm{~m}, \mathrm{c}=0.3 \mathrm{~m})$

\section{Discussion}

Material hydraulic properties, particularly the particle size distribution, water retention characteristics, and $K_{s}$ of the cover (coarse sandy loam) were adequate for the establishment and growth across all species, with the exception of $A$. alata. Deaths in this species are likely a result of poor seedling quality, or an inability to establish sufficient roots in the cover prior to the dry season leading to desiccation. Cover thickness did not play a significant role in growth during these early stages of development, although in the three fastest growing species, seedlings on the thickest cover tended to grow most. Growth differences between cover thicknesses may have been largely suppressed due to the availability of water from irrigation. It is likely that under non-irrigated conditions, growth differences between cover thickness treatments would have been more apparent, as top soils would have dried out and seedlings would have been more dependent on stored water in deeper soil layers. Significant differences in growth were only present between species and were associated with the different genera. Growth rate differences at the species and genus level may have important implication for the design of ET covers, with regard to the long-term community composition of the system. Choosing species with higher growth rates like A. acuminata (Figure 3 ) may lead to better immediate vegetation coverage and water extraction thus increasing initial ET performance. However, it is important to consider that species with high initial biomass production and water use may outcompete species with slower biomass production and water use (Zea-Cabrera et al. 2006), eventually resulting in decreased ET cover performance (Smesrud et al. 2011). Additionally, the co-existence of species with varying growth and water use strategies may be necessary to attain balanced transpiration on ET covers (Gwenzi et al. 2014). The combination of varying root strategies, e.g. deep versus shallow roots, and the heterogeneous 
distribution of hydraulic soil properties characteristic of engineered covers (Gwenzi et al. 2011; Schneider et al. 2010) places important emphasis on the co-existence of species with varying growth rates, water use, and root strategies (Gwenzi et al. 2014). Therefore, during initial design phases species selection on ET covers should account for differences in growth and water use among species to ensure a robust community structure with balanced water extraction long-term.

Consideration must also be given to the seasonality of plant water extraction as seasonal shifts in transpiration and $g_{s}$ between winter and summer occurred at the site. During winter, plants sustained higher rates of transpiration and $\mathrm{g}_{\mathrm{s}}$. In summer, however, plants reduced their stomatal openings limiting transpiration (Figures 4 and 5), which was likely due to a combination of restricted plant available water in the root zone for thinner covers, and high VPDs associated with hot summer temperatures (Figures 1 and 2). Gwenzi et al. (2012) reported similar patterns of stomatal control for two evergreen shrub species, (Acacia rostellifera and Melaleuca nesophila), on a restored bauxite residue area where transpiration rates were four times higher in winter compared to summer. Seasonality associated with $\mathrm{g}_{\mathrm{s}}$ and transpiration due to shifts in root zone water occur naturally, and have previously been reported in Western Australia, particularly for shallow-rooted shrubs and herbaceous species (Veneklaas \& Poot 2003). In that study, the mean winter $g_{s}$ for all tree and shrub species was $0.3 \mathrm{~mol} \mathrm{~m}^{-2} \mathrm{~s}^{-1}$, which is lower than the mean winter value observed in this study $\left(0.4 \mathrm{~mol} \mathrm{~m}^{-2} \mathrm{~s}^{-1}\right)$. Additionally, mean summer $\mathrm{g}_{\mathrm{s}}$ values observed in this study $\left(0.2 \mathrm{~mol} \mathrm{~m}^{-2} \mathrm{~s}^{-1}\right)$ were slightly higher than those reported by Enright and Lamont (1992), which ranged from $0-0.12 \mathrm{~mol} \mathrm{~m}^{-2} \mathrm{~s}^{-1}$ for Banksia seedling growing on a restored mine site northeast of Perth in semi-arid WA. Seedling roots at this site were restricted to the top $0.1 \mathrm{~m}$ of the profile due to high subsoil mechanical impedance (Enright \& Lamont 1992). Higher winter and summer water use rates from our study compared to other studies from seasonally dry environments in WA may be due to species specific differences, and greater water availability on the ET cover originating from irrigation, as recorded rainfall during the experimental period was less than the long-term average for the site. Findings from our study suggest that extreme summer water loss was limited by stomatal closure in response to soil dryness and high VPD, while high winter $\mathrm{g}_{\mathrm{s}}$ and transpiration rates were supported by adequate soil water and low VPD.

Although differences in transpiration between cover thicknesses were not significant, which was likely due to a constant water supply provided by irrigation, the overall relationship suggests that transpiration increased with VWC, $g_{s}$, and cover thickness (Figure 5). Transpiration appears to be under stomatal control in response to drought stress as a result of cover thickness, which may indeed play a role in plant water use, and become more significant in the future without irrigation. Grigg et al. (2008) found similar results in an arid dune-interdune system where soil depth and texture in combination with their effects on water availability and root growth were the dominant factors affecting plant water use. Observed water use rates and VWC were lowest on the $0.3 \mathrm{~m}$ thick cover (Figures 2 and 4); assuming that water storage was negligible past $0.3 \mathrm{~m}$ (waste rock only), plant roots only had access to shallow soil water (0.0-0.3 $\mathrm{m}$ ) when compared to the thicker covers. Depletion of soil water by roots was greater on the $0.3 \mathrm{~m}$ thick cover due to its limited soil volume, which was demonstrated by low VWC at a $0.3 \mathrm{~m}$ depth compared to significantly higher VWCs at the same depth on the 0.5 and $0.7 \mathrm{~m}$ thick covers in summer and winter (Figure 2). Plants on thinner covers likely experienced greater drought stress resulting in tighter stomatal control and decreased transpiration (Enright \& Lamont 1992; Veneklaas \& Poot 2003; Szota et al. 2011). The significant interaction between $g_{s}$, VWC, and cover thickness occurred on the $0.5 \mathrm{~m}$ thick cover because transpiration increased with VWC at a faster rate (steeper slope) compared to other cover thicknesses. The interaction was likely the result of overland flow from the angled waste rock dump top caused by a large summer rainfall event (1 February 2015), which saw $27 \mathrm{~mm}$ of precipitation fall in two hours (Figures 1 and 2). Unimpeded flow from the angled waste rock dump top, over the slope, and onto the $0.5 \mathrm{~m}$ thick covers wetted VWC sensors at $0.1 \mathrm{~m}$ significantly compared to other cover thicknesses (Figure 2 ). The $0.7 \mathrm{~m}$ cover thickness was less affected due to its raised position on the slope, while the $0.3 \mathrm{~m}$ cover thickness was protected by small drainage channels at the top and sides of the plots. As physiological plant monitoring occurred eight days after the large rainfall event, large responses in transpiration rates from plants on the $0.5 \mathrm{~m}$ covers were likely captured resulting in a significant interaction. 
Despite higher mean VWC (from 0.0-0.3 m) on the $0.5 \mathrm{~m}$ cover compared to the $0.7 \mathrm{~m}$ cover, overall transpiration was still greater on the $0.7 \mathrm{~m}$ cover. Greater water use and lower VWC from $0.0-0.3 \mathrm{~m}$ on the $0.7 \mathrm{~m}$ thick cover (Figures 4 and 5) may indicate that these plants depleted soil water from shallower depths and accessed it deeper in the profile (Figure 2). When soil water is limiting it is not uncommon for plants to remain physiologically active by accessing deeper reserves. For instance, species occurring on deeper dunes had significantly higher $\mathrm{g}_{\mathrm{s}}$ compared to species occurring on shallower interdunes due to increased water storage and deep root exploration provided by greater soil volume (Grigg et al. 2008). However, when making community level comparisons it is important to recognise that not all species within a community will possess the same root depths or water use patterns (Smesrud et al. 2011; Poot \& Veneklaas 2013). Nonetheless, greater plant water use on thicker covers may be the result of increased water storage, and plant root access to deeper available water. Providing that material hydraulic properties are conducive to water retention; this work presents valuable evidence suggesting that thicker covers may increase water storage resulting in increased water use at the community level, which is in part regulated by plant stomatal control.

\section{$5 \quad$ Summary and conclusion}

This study demonstrates the importance of quantifying growth and water use differences at the community level, between seasons, and cover thicknesses. Plant height growth differed significantly between species, with species of the same genus behaving similarly. Growth rate differences at the species and genus level may be important during species selection for revegetation of ET covers, especially with regard to the long-term community composition. Differences in growth between cover thicknesses were not apparent and may have been suppressed by the availability of water from irrigation. Further ecophysiological monitoring will be conducted under non-irrigated conditions, and include further characterisation of growth, root morphology, physiology and water use for the experimental species.

During design phases cover system engineers, modellers, and restoration practitioners must also account for the seasonality of plant water use in water limited systems. Low summer water use rates were mediated by stomatal closure in response to soil dryness and high VPD, while high winter rates were facilitated by open stomates due to adequate plant available water and low VPD. Integrating the seasonality of plant water use into cover system models would likely improve predictions of ecophysiological and hydrological behaviour on ET covers, especially in semi-arid to arid climates.

One monitoring year from the irrigated ET cover demonstrated that transpiration rates and $\mathrm{g}_{\mathrm{s}}$ increased with cover thickness $(0.7>0.5>0.3 \mathrm{~m})$, although not statistically significant which is likely due to the presence of irrigation. Water use was regulated by strong stomatal control of transpiration in response to drought stress associated with cover thickness. Plant roots on thicker covers likely accessed water stored deeper in the cover profile, while those growing on thinner covers where likely inhibited by the shallower waste rock layer, limited soil volume, and less stored soil water. Plants on thinner covers only had access to shallow soil water increasing their probability of drought stress leading to stomatal closure and overall lower water use rates. The relationship between transpiration, $\mathrm{g}_{\mathrm{s}}, \mathrm{VWC}$, and cover thickness improves our understanding of plant ecophysiology on ET covers, however, quantifying the effects of overland flow on all cover thicknesses would likely improve our understanding of this relationship and water inputs into the system. Moving forward the study will be conducted under non-irrigated conditions, likely leading to greater differences in stored water, plant water use, and growth. This study highlights the use of cover thickness as a rehabilitation option that should be considered during cover design to optimise ET cover functionality, and aid the establishment of persistent plant communities on ET covers. Future work should centre on the calibration and validation of soil-plant-atmosphere and hydrological models using available soil, plant, and weather data from this and future ecophysiological studies on ET covers. Improvements to plant ecophysiological modules in current and future models will provide robust estimates of cover system water balances, leading to improved cover system modelling and design of ET covers in water limited systems. 


\section{Acknowledgement}

We are grateful for the research funding provided by O'Kane Consultants Inc. over the entirety of this PhD project. We also thank Mount Gibson Mining Limited for providing the field site, an operating budget, and logistical support: specifically Jessica Sackmann, Michelle Holland, Ashley Bell, Ben O'Grady, Andrew Thomson, and the Extension Hill Hematite Operation staff. We gratefully acknowledge the volunteers who dedicated much time and effort during field work: Nicolas Pinceloup, Maggie Triska, Felipe Albornoz Ramirez, Kyle Mart and Ruebendraa Kantahrao.

\section{References}

Albright, WH, Benson, CH, Gee, GW, Roesler, AC, Abichou, T, Apiwantragoon, P, Lyles, BF \& Rock, SA 2004, 'Field Water Balance of Landfill Final Covers', Journal of Environmental Quality, vol. 33, no. 6, pp. 2317-2332.

Arnold, S, Schneider, A, Doley, D \& Baumgartl, T 2015, 'The limited impact of vegetation on the water balance of mine waste cover systems in semi-arid Australia', Ecohydrology, vol. 8, no. 3, pp. 355-367.

Arora, V 2002, 'Modeling vegetation as a dynamic component in soil-vegetation-atmosphere transfer schemes and hydrological models', Reviews of Geophysics, vol. 40, no. 2, p. 1006.

ATA Environmental 2006, Mt. Gibson Magnetite Project Supplementary Vegetation and Flora Surveys, prepared for Mt. Gibson Iron Ltd. Australian Standard 1289.3.6.1 2009, Standard method of analysis by sieving in Methods of testing soils for engineering purposes Soil classification tests - Determination of the particle size distribution of a soil, SAI Global.

Australian Standard 1289.6.7.1 2001, Constant head method for a remoulded specimen in Methods of testing soils for engineering purposes - Soil strength and consolidation tests - Determination of permeability of a soil, SAI Global.

Bates, D, Maechler, M, Bolker, B \& Walker, S 2014, Ime4, Ime4: Linear mixed-effects models using Eigen and S4. R package version 1.1-7.

Bennet Environmental Consulting 2000, Flora and Vegetation of Mt. Gibson, prepared for Mt. Gibson Iron Ltd.

Bhaskar, R \& Ackerly, DD 2006, 'Ecological relevance of minimum seasonal water potentials', Physiologia Plantarum, vol. 127, no. 3, pp. 353-359.

Bohnhoff, G, Ogorzalek, A, Benson, C, Shackelford, C\& Apiwantragoon, P 2009, 'Field data and water-balance predictions for a monolithic cover in a semiarid climate', Journal of Geotechnical and Geoenvironmental Engineering, vol. 135, no. 3, pp. 333-348.

Botros, FE, Harter, T, Onsoy, YS, Tuli, A \& Hopmans, JW 2009, 'Spatial Variability of Hydraulic Properties and Sediment Characteristics in a Deep Alluvial Unsaturated Zone', Vadose Zone Journal, vol. 8, no. 2, pp. 276-289.

Bristow, KL, Campbell, GS \& Calissendorff, C 1984, 'The Effects of Texture on the Resistance to Water Movement within the Rhizosphere1', Soil Science Society of America Journal, vol. 48, no. 2, pp. 266-270.

Eamus, D, Yunusa, I, Taylor, D \& Whitley, R 2013, 'Design of store-release covers to minimize deep drainage in the mining and waste-disposal industries: results from a modelling analyses based on ecophysiological principles', Hydrological Processes, vol. 27, no. 26, pp. 3815-3824.

Enright, NJ \& Lamont, B 1992, 'Survival, Growth and Water Relations of Banksia Seedlings on a Sand Mine Rehabilitation Site and Adjacent Scrub-Heath Sites', Journal of Applied Ecology, vol. 29, no. 3, pp. 663-671.

Fayer, MJ \& Gee, GW 2006, 'Multiple-Year Water Balance of Soil Covers in a Semiarid Setting', Journal of Environmental Quality, vol. 35, no. 1, pp. 366-377.

Gee, GW, Benson, CH \& Albright, WH 2006, 'Comment on "Evaluation of Evapotranspirative Covers for Waste Containment in Arid and Semiarid Regions in the Southwestern USA"', Vadose Zone Journal, vol. 5, no. 2, pp. 809-812.

Griffin and Associates 2005, Numerical Analysis of Floristic Data in Mt. Gibson Area, prepared for ATA Environmental.

Grigg, AM, Veneklaas, EJ \& Lambers, H 2008, 'Water relations and mineral nutrition of closely related woody plant species on desert dunes and interdunes', Australian Journal of Botany, vol. 56, no. 1, pp. 27-43.

Gwenzi, W, Hinz, C, Bleby, TM \& Veneklaas, EJ 2014, 'Transpiration and water relations of evergreen shrub species on an artificial landform for mine waste storage versus an adjacent natural site in semi-arid Western Australia', Ecohydrology, vol. 7, no. 3, pp. 965-981.

Gwenzi, W, Hinz, C, Holmes, K, Phillips, IR \& Mullins, IJ 2011, 'Field-scale spatial variability of saturated hydraulic conductivity on a recently constructed artificial ecosystem', Geoderma, vol. 166, no. 1, pp. 43-56.

Gwenzi, W, Veneklaas, EJ, Bleby, TM, Yunusa, IAM \& Hinz, C 2012, 'Transpiration and plant water relations of evergreen woody vegetation on a recently constructed artificial ecosystem under seasonally dry conditions in Western Australia', Hydrological Processes, vol. 26, no. 21, pp. 3281-3292.

Hacke, UG, Sperry, JS, Ewers, BE, Ellsworth, DS, Schäfer, KVR \& Oren, R 2000, 'Influence of soil porosity on water use in Pinustaeda', Oecologia, vol. 124, no. 4, pp. 495-505.

Jury, WA \& Horton, R 2004, Soil physics sixth edition, New Jersey, USA, John Wiley \& Sons.

Landloch Pty Ltd 2012, Design of the Hematite Waste Dump, Extension Hill Operation, prepared for Mount Gibson Iron Ltd.

LI-COR Inc. 2011, Using the LI-6400 / LI-6400XT Portable Photosynthesis System, Lincoln, Nebraska.

McKenzie, N, McKenna, S, May, J \& Australia, W 2003, Bioregional summary of the 2002 Biodiversity audit for Western Australia, Department of Conservation \& Land Management.

Meissner, R \& Caruso, Y 2008, 'Flora and vegetation of banded iron formations of the Yilgarn Craton: Mount Gibson and surrounding area', Conservation Science Western Australia, vol. 7, no. 1, pp. 105-120. 
Muñoz-Carpena, R, Regalado, C \& Alvarez-Benedi, J 2001, 'The Philip-Dunne permeameter: a low-tech/low-cost field saturated hydraulic conductivity device', ASAE Paper, no. 01-2146.

Muñoz-Carpena, R, Regalado, CM, Álvarez-Benedi, J \& Bartoli, F 2002, 'Field evaluation of the new philip-dunne permeameter for measuring saturated hydraulic conductivity', Soil Science, vol. 167, no. 1, pp. 9-24.

O'Kane, M \& Ayres, B 2012, 'Cover systems that utilise the moisture store-and-release concept-do they work and how can we improve their design and performance', in Proceedings of the Seventh International Conference on Mine Closure, Brisbane.

Ogorzalek, A, Bohnhoff, G, Shackelford, C, Benson, C \& Apiwantragoon, P 2008, 'Comparison of Field Data and Water-Balance Predictions for a Capillary Barrier Cover', Journal of Geotechnical and Geoenvironmental Engineering, vol. 134, no. 4, pp. 470-486.

Payne, A 1997, An inventory and condition survey of the Sandstone-Yalgoo-Paynes Find area, Western Australia, Department of Agriculture.

Pérez-Harguindeguy, N, Díaz, S, Garnier, E, Lavorel, S, Poorter, H, Jaureguiberry, P, Bret-Harte, MS, Cornwell, WK, Craine, JM, Gurvich, DE, Urcelay, C, Veneklaas, EJ, Reich, PB, Poorter, L, Wright, IJ, Ray, P, Enrico, L, Pausas, JG, de Vos, AC, Buchmann, N, Funes, G, Quétier, F, Hodgson, JG, Thompson, K, Morgan, HD, ter Steege, H, van der Heijden, MGA, Sack, L, Blonder, B, Poschlod, P, Vaieretti, MV, Conti, G, Staver, AC, Aquino, S \& Cornelissen, JHC 2013, 'New handbook for standardised measurement of plant functional traits worldwide', Australian Journal of Botany, vol. 61, no. 3, pp. 167-234.

Pinheiro, J, Bates, D, DebRoy, S, Sarkar, D \& Team, RC 2015, nlme: Linear and Nonlinear Mixed Effects Models, R package version 3.1-121 http://CRAN.R-project.org/package=nlme

Poot, P \& Veneklaas, E 2013, 'Species distribution and crown decline are associated with contrasting water relations in four common sympatric eucalypt species in southwestern Australia', Plant and Soil, vol. 364, no. 1-2, pp. 409-423.

R Core Team 2013, R, 'R: A language and environment for statistical computing v0.98.1028. R Foundation for Statistical Computing', Vienna, Austria, http://www.R-project.org/

Scanlon, BR, Levitt, DG, Reedy, RC, Keese, KE \& Sully, MJ 2005a, 'Ecological controls on water-cycle response to climate variability in deserts', in Proceedings of the National Academy of Sciences, vol. 102, no. 17, pp. 6033-6038.

Scanlon, BR, Reedy, RC, Keese, KE \& Dwyer, SF 2005b, 'Evaluation of Evapotranspirative Covers for Waste Containment in Arid and Semiarid Regions in the Southwestern USA', Vadose Zone Journal, vol. 4, no. 1, pp. 55-71.

Schneider, A, Baumgartl, T, Doley, D \& Mulligan, D 2010, 'Evaluation of the Heterogeneity of Constructed Landforms for Rehabilitation Using Lysimeters', Vadose Zone Journal, vol. 9, no. 4, pp. 898-909.

Seyfried, MS, Schwinning, S, Walvoord, MA, Pockman, WT, Newman, BD, Jackson, RB \& Phillips, FM 2005, 'Ecohydrological control of deep drainage in arid and semiarid regions', Ecology, vol. 86, no. 2, pp. 277-287.

Smesrud, JK, Benson, CH, Albright, WH, Richards, JH, Wright, S, Israel, T \& Goodrich, K 2011, 'Using Pilot Test Data to Refine an Alternative Cover Design in Northern California', International Journal of Phytoremediation, vol. 14, no. sup1, pp. 76-93.

Sperry, JS \& Hacke, UG 2002, 'Desert shrub water relations with respect to soil characteristics and plant functional type', Functional Ecology, vol. 16, no. 3, pp. 367-378.

Sperry, JS, Adler, FR, Campbell, GS \& Comstock, JP 1998, 'Limitation of plant water use by rhizosphere and xylem conductance: results from a model', Plant, Cell \& Environment, vol. 21, no. 4, pp. 347-359.

Szota, C, Veneklaas, EJ, Koch, JM \& Lambers, H 2007, 'Root Architecture of Jarrah (Eucalyptus marginata) Trees in Relation to Post-Mining Deep Ripping in Western Australia', Restoration Ecology, vol. 15, pp. S65-S73.

Szota, C, Farrell, C, Koch, JM, Lambers, H \& Veneklaas, EJ 2011, 'Contrasting physiological responses of two co-occurring eucalypts to seasonal drought at restored bauxite mine sites', Tree Physiology, vol. 31, no. 10, pp. 1052-1066.

Veneklaas, E \& Poot, P 2003, 'Seasonal patterns in water use and leaf turnover of different plant functional types in a species-rich woodland, south-western Australia', Plant and Soil, vol. 257, no. 2, pp. 295-304.

von Caemmerer, S \& Farquhar, GD 1981, 'Some relationships between the biochemistry of photosynthesis and the gas exchange of leaves', Planta, vol. 153, no. 4, pp. 376-387.

Yunusa, IAM, Zeppel, MJB, Fuentes, S, Macinnis-Ng, CMO, Palmer, AR \& Eamus, D 2010, 'An assessment of the water budget for contrasting vegetation covers associated with waste management', Hydrological Processes, vol. 24, no. 9, pp. 1149-1158.

Zea-Cabrera, E, Iwasa, Y, Levin, S \& Rodríguez-Iturbe, I 2006, 'Tragedy of the commons in plant water use', Water Resources Research, vol. 42, no. 6.

Zuur, A, leno, EN, Walker, N, Saveliev, AA \& Smith, GM 2009, Mixed effects models and extensions in ecology with R, Springer. 